\title{
IN SEARCH OF ATHEISM: \\ BENJAMIN AND NIETZSCHE ON SECULARITY AND OCCULT THEOLOGIES
}

\author{
James Martel \\ San Francisco State University, Department of Political Science
}

Recibido: 27.06.2019 - Aceptado: 21.11.2019

\begin{abstract}
In this article, I argue that atheism is different from secularism. Secularism is based on a faux elimination of theology which effectively preserves that theology in the guise of overcoming it. To achieve atheism (a term that I draw from the work of Maria Aristodemou), I argue that one needs to directly confront the theological element in order to come to terms with it. In this essay I look at how two political theological thinkers, Nietzsche and Benjamin, accomplish this. Nietzsche accomplishes atheism via his thesis of the "death of God," a death that is not always literal but which creates a space for human life that is not determined by theological terms. Benjamin does the same thing with his idea that God vacates divine powers of judgment and determination in order to allow an atheistic space where human beings can engage in their own self-determination (even as the notion of God remains to challenge any would be human spokespersons for that role). I ultimately argue that atheism and anarchism are related concepts based not just on a rejection of certain forms of theology and all forms of archism, but also in terms of the way they allow a positive and undetermined human response.
\end{abstract}

Keywords: Atheism; Nietzsche; Benjamin; Secularism; Anarchism. 


\section{INTRODUCTION: CAN WE EVER BE ATHEISTS?}

In her book Law, Psychoanalysis, Society, Maria Aristodemou describes her understanding of atheism as a form of "freedom from symbolic links, where the empty place is acknowledged and confronted in all its abyssal emptiness rather than being filled with idolatrous gods from laws to goods." ${ }^{1}$ She goes on to say that with atheism, "the Other... is finally acknowledged to be just like the subject herself: divided, lacking, impotent." ${ }^{2}$ Based on this understanding, I would argue that atheism is ultimately an anarchic condition wherein the Big Other (to stay for a moment in Aristodemou's Lacanian parlance) loses its privileged perch vis a vis the subject. When the Big Other is understood as a kind of ultimate subject —either God or some other kind of archon — one's own individual subjectivity is inevitably deemed lesser. Hierarchy is built into the kind of psychic networks that come from a belief in the wholeness of the Big Other. After all, each of us has to acknowledge the division of our own self; that division is the basis of who we are whereas the Big Other, being entirely external to us, appears to be unified. And this is true, not just for individuals - whose own sense of autonomy is arguably a production of the kind of divide and conquer politics that the belief in Big Others tend to produce - but also for collectivities, for groups of similarly riven subjects whose split identity similarly occurs on the collective level as well.

This division between the divided and the non-divided is, in a sense the basis (or at least a basis) for what I would call archism, a political system based on hierarchy, rank and illicit forms of authority. If the Big Other is better than me, than it deserves to rule over or at least represent me in my political life (thereby ensuring that I don't have a political life of my own). If it is whole while I am broken then it knows better, knows more, knows even what is in my own best interest when I myself couldn't possibly know any such thing (insofar as there is no solid "me" to know anything by or from). The authority that is produced from this relationship is illicit because it is based on a lie: the idea that the Big Other is what it says it is. Knowing itself that it is not in fact whole, the Big Other - or whatever archist manifestation this psychic entity takes-Is always anxious to protect the myth of its wholeness, leading to violence, racism, misogyny and various other trappings of archist power.

\footnotetext{
${ }^{1}$ Aristodemou 2014, 108 .

${ }^{2}$ Ibid.
} 
In this paper I will try to think about how to achieve atheism, that is to say how to come to a state of being wherein the false hierarchies of archism are subverted and disallowed, making way for a form of an-archism in the process. ${ }^{3}$ Although Aristodemou remains largely in a psychoanalytic and Lacanian register, her use of the term atheism suggests the theological origins of archism. As we saw, she speaks of "idolatrous gods" who we must cease to worship. These "gods" include many secular concepts; "from laws to goods." But even these secularities are, as she notes, forms of gods, forms of idolatry which superimposes a wholeness on what is always and necessarily divided (hence mortal, hence not a god at all). Secularism itself is thus a matter of theology. More accurately it is a pseudo theology where earthly things are endowed with sacred aspects that give them secular power (hence idolatrous).

As writers ranging from Ernst Kantorowicz to Max Weber have noted, the secular modern world is built on the basis of ongoing theological structures. ${ }^{4}$ In this sense, to borrow from Bruno Latour, we have never been truly secular; or rather, modern day archism is secular but it is no less theological for all of that. If secularity as such is not actually post-theological then it does not contain the basis by which to overcome the darker political aspects that this encrypted theology produces for us. ${ }^{5}$ What we need, I will claim, is not secularism but atheism. The question I will pose then is how do we achieve this form of atheism? My argument will be that to actually achieve atheism, only a counter theology will do. We need to fight the fire of encrypted and archist theology with the fire of a radical and decrypted atheology. To free ourselves from false gods we need some recourse to other gods (or God(s)) to free ourselves once and for all from divine interference of whatever origin.

Accordingly, in this chapter I will look at the counter theological aspects of two well- known thinkers, Friedrich Nietzsche and Walter Benjamin, followed by a consideration of Kafka's The Castle which I will claim practices in its texts the very atheistic practices that Nietzsche and Benjamin theorize.

The shared counter-theological approach for all of these three authors amounts to employing the figures of theology (and in particular those figures from Abrahamic theology) wherein prophets, messiahs and God ruin and subvert the occult theologies that they normally serve to produce and which underlie our contemporary political and economic practices (that is to say, archism). To return temporarily to Aristodemou's Lacanian parlance, when the Real Big Other (that

${ }^{3}$ Among "fellow travelers" in the search for an atheistic anarchism, I would definitely include Saul Newman, particularly in his recent book Political Theology: A Critical Introduction. In that book he speaks of theology as an "absent presence" in our current moment, something that has to be "displaced." (Newman, 2019, 19).

${ }^{4}$ See Kantorowicz 1957, Weber 1985.

${ }^{5}$ For more on the idea of encryption, see Sanín-Restrepo 2016. 
is to say, God) demonstrates the falseness of those who pose as such on earth, then those positions are ultimately destroyed. The trick here, and this is what I will be focusing on the most in what follows, is that these thinkers do not allow the workings of these counter theological figures to replace one set of idolatries with another. Their depiction of acts of what Benjamin calls divine violence tend to collapse upon themselves so that the effect of the salvations that these figures engage in serves to save us in the end from salvation-with all of the archist seduction, threat and deception that this involves - as such. If we need God to get rid of gods, this God closes the door between the divine and the human, leaving us, at least for a time, alone and atheist, without any recourse to an externality that ceaselessly serves as a basis for further archism. On that basis, the anarchist life that we lead when it is not superseded or eclipsed by archism (although it carries on even when it is) emerges into its greater visibility, something that my reading of The Castle will attempt to show more clearly.

\section{POST-SECULARISM}

In order to situation this discussion to some extent, I would like to briefly consider the question of "post-secularism" to show a deeper difference between secularity and atheism that I am trying to establish. The post-secular movement can be seen as a reaction against the assumptions in secularism wherein theological questions have been resolved once and for all in favor of an entirely rationalist and materialist form of thought. One of the most important voices of post-secularism is William Connolly. In many books and articles, he has laid out a theory that allows for what he calls "transform[ing] the Kantian transcendental field to a layered, immanent field." That is to say, Connolly seeks to reassert the transcendent - a realm that he has stripped of a lot of the preconditions and determination that Kant, as well as many other enlightenment thinkers have embued it with-- as a way to reconsider the material world and our place in it. In doing so, Connolly does not abandon the secular tradition so much as infuse it with precisely what it seeks to distinguish itself from. Elsewhere, Connolly speaks of:

"new possibilities of cross-fertilization between devotees of divine transcendence who concentrate creativity in God (not all devotees of transcendence do so) and devotees of a world immanent to itself who... admit differential degrees of real agency and creativity into a variety of natural and social processes". 7

\footnotetext{
${ }^{6}$ Connolly 2002, 84.

${ }^{7}$ Connolly 2011, 21.
} 
In this way, divinity is not meant to be read out of the world (as secularism purports to do) but is rather meant to serve as a way for materiality to get some perspective on itself. ${ }^{8}$

Other important Post-secularists include Talal Assad, Roberto Unger and Saba Mahmood. ${ }^{9}$ These writers vary in terms of their own relationship to secularism but all of them reflect the notion that theology has in fact never lost its relevance. They point to the way that the theological is not only continually adhered to by vast numbers of people but also that it serves to explain the world in ways that secularism never quite could (in part because secularism has never been truly secular).

My argument here is not with post-secularism itself — certainly not with any of the authors listed above - so much as it with the notion that secularism itself is in any way a-theological and that therefore being post-secularism represents a "return" to theology; as previously noted, there has never been a need for secularism to return to a form of thought that is inherent in itself. ${ }^{10}$ As I see it, post-secularism is more of an acknowledgment of and direct address to the cryptic theologies that have always remained key to secularism.

Atheism, at least in terms of the way that Aristodemou uses that term, is different. Atheism directly acknowledges the role and power of theology in political and material life. Instead of denying the role of theology (as secularism does) or openly acknowledging the ongoing role of theology (as post-secularism does), atheism faces down the theological directly, engaging with it in order to finally release us - if not once and for all then at least episodically and provisionally - from its stubborn embrace. By "traversing the fantasy" of the theological (to use another Lacanian term), atheism finds a way to finally disengage with the theological, whether by proclaiming that "God is dead" as Nietzsche does - more on that shortly — or realizing that the Big Other is just another self, as previously noted. Although, as I will argue in this paper, sometimes one needs the help of God or of gods to fight the fire of theology with the fire of a corresponding counter-theology, the upshot of atheism is a state of non-engagement that secularity has long promised but never actually delivered upon.

\footnotetext{
${ }^{8}$ See Connolly 1999 as well Connolly 2011, 648-56.

9 See Asad 2003, Mangabeira Unger 2016, Mahmood 2015. See also Critchley 2014; Asad, Brown, Butler, Mahmood 2013.

${ }^{10}$ In Difficult Atheism, Christopher Watkin writes that the death of God "merely replaces 'God' with a supposedly atheistic placeholder...explicitly rejecting but implicitly imitating theology's categories of thinking." Watkin 2011, 1-2. Here, Watkin seems to be using atheism in a somewhat different way than I am.
} 


\section{NIETZSCHE AND THE DEATH OF GOD}

Having better established what I mean by atheism, let me begin the discussion proper with a consideration of the counter-theological work of Nietzsche and Benjamin insofar as I think it helps to set the stage for what we experience in The Castle as well. On the surface of things these two seem to be opposites. After all, Nietzsche is famous for proclaiming the "death of God" and Benjamin is an explicitly theological thinker; his Marxism, as is well known, is intermixed with a large amount of Jewish mysticism. Yet, upon closer examination, it becomes clear that Nietzsche and Benjamin share a kind of counter-theological inclination. ${ }^{11}$

While both philosophers offer us various counter-theological figures that serve to foment atheism (Nietzsche's Zarathustra and the overman are two prime examples, Benjamin's Angel of History is another), for the sake of space and simplicity, I would focus only on their respective treatments of God, beginning with Nietzsche. ${ }^{12}$ As is very well known, Nietzsche tells us quite plainly that God is dead. For example, in Section 108 of The Gay Science, Nietzsche writes that "God is dead; but given the way of men, there may still be caves for thousands of years in which his shadow will be shown.-And we-we still have to vanquish his shadow too." ${ }^{\prime 3}$ Here we can see from the outset that the fact that God is dead does not prevent but in fact can be seen as a cause for the fact that God is experienced by human beings only in shadow form (if God was alive, it would be fair to say that we might experience God as God; that possibility at least would exist as a way to distinguish between God and shadow). ${ }^{14}$

Yet, even God's “death" can be put to question. At one point well into Thus Spoke Zarathustra (in Part IV which is admittedly the most apocryphal section of the book), Zarathustra comes to his cave to see that the many people that he has encountered on the road and who came to the cave to await the coming of a

\footnotetext{
${ }^{11}$ For an understanding of theology as a kind of counter-measure to religion, see Andrew Benjamin 2013, 2.

${ }^{12}$ I am currently working on a book project entitled Disappointing Vision: Anarchist Prophecy and the Power of Unseeing where I look at these prophetic figures more closely.

${ }^{13}$ Nietzsche 1974, 167.

${ }^{14}$ For more on the idea that "God is dead," see Heidegger 2002. In that essay, Heidegger states "After the metaphysical reversal carried out by Nietzsche, all that is left to metaphysics is to be inverted into the dire state of its non-essence. The supersensory has become an unenduring product of the sensory. But by so disparaging... its antithesis, the sensory denies its own essence. The dismissal... of the supersensory also eliminates the purely sensory and with it the difference between the two." Ibid., 157. As Marie Chabbert interprets this and other such sentiments as telling us that "As far as Heidegger is concerned... Nietzsche's residual atheism not only fails to destroy God's transcendent 'place,' it is also complicit with filling it anew [i.e. with replacing the "God-Man with the Man-God"]." Chabbert 2018, 54. For other thinkers on this issue, see for example, Girard 1988). See also Deleuze 1983. Deleuze describes this as a form of "violent atheism" (Ibid., 4).
} 
transcendent being called "The Higher Man" suddenly start worshipping a donkey who is one of their company.

Zarathustra turns on his would be followers, asking how it is possible that they not only have decided that God is now alive again but that God took this particular form. One such follower called the "wanderer and the shadow" (speaking of shadows in caves!) tells Zarathustra that:

"you are right: but what can I do? The old God lives again, Zarathustra, you may say what you will!

It is all the fault of the ugliest man [another of Zarathustra's followers]: he has awakened him again. And if he says that he once killed him: with gods death is always only a prejudice." 15

Turning to the ugliest man himself, Zarathustra asks him: "Is it true what they say, that you have awakened him again? And why? Was he not with reason killed and done away with?" To which the ugliest man replies: "Whether he still lives or lives again or is truly dead, which of us two knows best?"16

Here we see both the fact that God can, at least in theory, be brought back to life but also that it would be impossible to ultimately know one way or the other whether God was alive or dead (then again, why should we take the word of one of Zarathustra's followers who are so often depicted as crass and selfserving)?

God may be dead, and human beings may have killed him but the ultimate take away from this exchange is doubt, not doubt as to the existence of God in the first place but doubt about whether God has now stopped existing. Here we see that the shadows of God may not only be that; we can never know with certainty whether God still exists or not and hence God's shadow remains potentially effective. It might be a shadow or it might be the will or presence of God. It doesn't seem certain whether we could really know the difference.

Yet, for all of this, Nietzsche nonetheless puts great store and importance in the opposite possibility, that God might really be dead once and for all. Back in The Gay Science, he tells us that the idea of the death of God is so momentous that it is

"far too great, too distant, too remote from the multitude's capacity for comprehension even for the tidings of it to be thought of as having arrived as yet. Much less may one suppose that many people know as yet what this event really means - and how much must collapse now that this faith has been undermined because it was built upon this faith, propped

${ }^{15}$ Nietzsche 1969, 323.

${ }^{16}$ Ibid., 324. 
up by it, grown into it; for example, the whole of our European morality". ${ }^{17}$

Nietzsche tells us even those that are "born guessers of riddlers" (that is to say, those who see further than most, who struggle to know what can be known) don't quite understand this event but nonetheless they feel a great joy from its mere possibility. He writes:

"We philosophers and 'free spirits' feel, when we hear the news that 'the old god is dead', as if a new dawn shone on us...At long last the horizon appears free to us again, even if it should not be bright; at long last our ships may venture out again, venture out to face any danger...the sea, our sea, lies open again; perhaps there has never yet been such an 'open sea.",_18

This, I would argue, is an explicit vision of atheism, of an anarchic freedom from the dead hand of religion and morality and the various other modalities that come into our world from the presence of a God, a deity that knows and doesand determines - everything.

While the division between those who know and those who do not know may smack of a kind of elitism (something of which Nietzsche is very often accused), the very idea of the death of God suggests the opposite; to get rid of God is to get rid of the higher itself and hence eliminate even the very directionality by which we are normally judged. To remove God is to remove the ultimate source of all of the ways that the world is taxonomized into higher and lower, better and worse. Without such a yardstick, the universe becomes vastly more horizontal; indeed the very possibility of who would "know" something vs. who would not becomes impossible because knowledge and truth, which are ordinarily vouchsafed by a deity who knows everything, are no longer available for such judgments.

This tracks with a more general way in which Nietzsche often explodes the difference between shining and redemptive futures and ordinary presents, between halcyon heights and lowly depths. Nietzsche famously states in the opening to his Genealogy of Morals that "We knowers are unknown to ourselves." 19 He compares us to "a man divinely abstracted and self-absorbed into whose ears the bell has just drummed the twelve strokes of noon [and who] will suddenly awake with a start and ask himself what hour has actually struck." 20 This metaphor serves us well to understand Nietzsche's larger project. From our "divinely abstracted" position (dazzled, we could say, by the appearances of God and other

\footnotetext{
${ }^{17}$ Nietzsche 1974, 279.

18 Ibid., 280.

${ }^{19}$ Nietzsche 1956, 149.

${ }^{20}$ Ibid.
} 
Big Others), we have no sense of who or where - or when - we are. In fact, it is even worse even than might seem. It is not just that we don't know these things, it's that we don't want to know; we look to higher better states to promises of redemption and salvation (all the things that archism promises) in order to avoid being the fleshy, mortal beings that we are, stuck in an ordinary place in an ordinary time. For this reason, Nietzsche often entices us with promises of halcyon heights and so forth as a way to command our attention (that is the direction that we are trained to look) but he does so in order to redirect us back to where we actually are standing, to get us to "become what we are," to cite the subtitle of Ecce Homo. ${ }^{21}$

By reaching for these heights and failing, we have the potential, but only that, to cease our divine abstractions and re-read them as markers of the present, the here and the now, moving from theologically determined (and ranked) forms of time and space into a more human and atheistic mode. Here, we can begin to see further why Nietzsche tells us that God is dead. God serves as the ultimate sign of the heights that we wish to achieve. By "killing God," Nietzsche removes the very centerpiece of our abstraction, leaving us free and atheist, even if this freedom comes — at least initially_against our will.

Perhaps most critically of all, in The Gay Science, Nietzsche depicts a madman who jumps into a crowd crying "Whither is God?...I will tell you. We have killed him - you and I. All of us are his murderers." 22 This is important for thinking about the political upshot of the death of God because if we are simply taking Nietzsche's word for it, we remain passive subjects wherein Nietzsche himself becomes a kind of Big Other, a slayer of our foes who then becomes himself a kind of archon for us (in which case we'd just be replacing one god with another). If, on the other hand, he is simply pointing out that it is we ourselves who have killed God, Nietzsche draws us to our own agency, our freedom even from him.

At the end of the day, the question of whether God exists or not is perhaps of secondary importance to the fact that even if God does exist, that existence cannot be guaranteed. In depicting a God who comes in and out of existence, alternatively being killed and resurrected by human subjects (like the ugliest man), Nietzsche is delineating a space in which humans can be decolonized from occult forms of theism. In this way, not just atheism per se but even agnositicism (assuming this word encompasses both uncertainty about God's existence and also about God's current status even if existent) serve to make this radically emptied space available for us.

\footnotetext{
${ }^{21}$ See Nietzsche 1993.

${ }^{22}$ Nietzsche 1974, 181.
} 


\section{BENJAMIN AND THE ANARCHY OF GOD}

With Walter Benjamin, we find a very similar treatment of God even though Benjamin never contemplates the possibility that God could actually die. In his well-known distinction between mythic and divine violence, Benjamin lays out the terrain both for our oppression and resistance as political theological subjects. Mythic violence is the violence of projection, of false assertion, of archism itself. The state and the law are instances of mythic violence wherein these institutions, anxious about their own dubious and idolatrous origins, must repeatedly assert their existence by killing over and over again. This actual physical violence however is only a symptom of a deeper violence, the way these institutions must mystify their own sources of authority and connect them - even in secular times - to divine origins, thus standing in for and representing God on earth in some form or other, with all the powers and benefits that come along with such a representational stance.

For Benjamin, divine violence is the response to myth and idolatry. In the "Critique of Violence," he tells us that: "Mythic violence is bloody power over mere life for its own sake; divine violence is pure power over all life for the sake of the living. The first demands sacrifice; the second accepts it." ${ }^{23}$ Mythic violence will always have to assert itself against its own lack of ontological determination; it is always self-positing. Divine violence serves to unmake that positing. In doing so it serves not itself (as the state and the law do in terms of their relationship to mythic violence) but the living as a whole, an idea I will return to at the end of this paper."

Having said this, it is certainly true that Benjamin's depictions of God sometimes make the deity seem very archist indeed. The main story that Benjamin uses in the "Critique" to discuss divine violence is the story of Korah, a Levite priest who, along with his followers challenged Moses' authority to speak to and on behalf of God. In having Korah and his followers swallowed into the ground, leaving no trace of their existence behind so that even their sins are removed, it seems as if God is punishing people for making their own assertions. Certainly this act does nothing to reduce the impact of God's authority over human beings more generally.

Yet elsewhere in Benjamin's work we see evidence that divine violence doesn't always work this way. One writing of Benjamin's in particular, a fragment entitled "the Meaning of Time in the Moral Universe," suggests a very different deity. There, Benjamin speaks of how God postpones the Last Judgment, possibly forever. He writes:

\footnotetext{
${ }^{23}$ W. Benjamin 1996, 250.
} 
"The Last Judgment is regarded as the date when all postponements are ended and all retribution is allowed free rein. This idea, however, which mocks all delay as vain procrastination, fails to understand the immeasurable significance of the Last Judgment, of that constantly postponed day which flees so determinedly into the future after the commission of every misdeed. which flees so determinedly into the future after the commission of every misdeed." 24

Calling the Last Judgment "that constantly postponed day," suggests that even if human beings deserve judgment, punishment, hierarchy and taxonomization (who is good, who is bad etc), all the bases of archist power, God may not actually enforce this rule upon us. In that same fragment, Benjamin describes a "tempestuous storm of forgiveness which precedes the onrush of the Last Judgment," a form of divine violence that serves not only to unmake the lies and myths that human beings ascribe to God but even that divine power that belongs properly to God. ${ }^{25}$

In this way, however paradoxical this may seem, God can be seen as the ultimate source of atheism. Benjamin therefore doesn't need to resort to killing God (as Nietzsche does and which, as we saw, doesn't always produce the desired results anyway insofar as God doesn't necessarily stay dead) but rather enlists God as the ultimate conveyer of atheism; it is God and not her absence, Benjamin suggests, which creates a space for human beings that is free from divine interference. When Benjamin tells us elsewhere that divine violence serves the living, we see in "the Meaning of Time in the Moral Universe" just how that service works. Rather than extending divine mandates in the same way that mythic violence serves to augment its own power and authority, God works in this case against her own divine authority, carving out a space that actually comes at God's own expense.

Taking Nietzsche and Benjamin together, we can see that in both cases, they have enlisted God to serve as a basis for atheism. Whether that enlistment comes in the form of killing God or simply seeing God as the ultimate anarchist, in either case God radically subverts the very order which that theology is normally meant to support. This serves as a kind of "hair of the dog" strategy (akin to the pharmakon that Derrida describes with Plato) wherein the only way to counter a hidden theological influence is to oppose it with a theological element which is not merely interested in its own power and authority. ${ }^{26}$ Whether she is rendered dead or subversive, these renditions of God serve to close, as it were, the door between the divine and the human. Here, God's own actions (or lack therein) cannot become the basis of a new and greater idolatry. By withdrawing

\footnotetext{
${ }^{24}$ W. Benjamin 1996, 286.

${ }^{25}$ Ibid.

${ }^{26}$ See Derrida1983.
} 
from the world (whether via death or voluntary removal) these depictions of God show how this can be done.

\section{THE CASTLE: A VIEW FROM BELOW}

These modes of producing atheism may work at the level of philosophy or political theology, but (how) do they work at the level of human life? After all, if divine violence is indeed, as Benjamin tells us, meant for the living, then how can the living understand and engage with what is after all a force that is infinitely beyond human understanding or control? And furthermore, doesn't it jeopardize human autonomy, the very possibility of atheism itself, to set above it these visions of a God who either flickers in and out of being alive or decides to give us the space for our own freedom (a decision that could very easily be reversed)? Isn't any engagement with God automatically suspect from this perspective?

In order to think further about these kinds of questions I would turn my attention away from Nietzsche and Benjamin and look to a work of fiction, Kafka's The Castle, as a way to better comprehend how this move towards atheism looks from the human perspective. The Castle may appear to be a strange book to evoke in terms of atheism because, to the degree that it can be read as relating to theology, it seems that there is nothing but theism in these pages. The question of whether this book really is about theology can be, has been, debated. Max Brod certainly thought so but he has come under a great deal of criticism for oversimplifying or misdirecting Kafka's own meanings and purposes. ${ }^{27}$ I would say that the book could be read variously as a commentary on theology, politics and or law and that the very incommensurabilty of being able to definitively say what it is about speaks to the way that theology has merged with politics and other related fields in our own time.

\section{LEARNING TO SEE THE CASTLE}

The plot of The Castle revolves around the arrival of K., purportedly a land surveyor to a village that is dominated (so we are told) by a giant castle. Even that central fact is debatable insofar as it seems as if $\mathrm{K}$. has learned how to see a castle that isn't necessarily there. K. arrives to the village at night and says of his first "sighting" that:

${ }^{27}$ See for example Cohn 2011, 308. Benjamin's reading of Kafka differed from Gershom Scholem's as can be seen, for example, in some of the letters between them. See Scholem (ed.) 1992. For some commentary on this, see, for example, Alter 1999, 149-167. To the extent that Scholem is sometimes considered to be an anarchist himself, I would place him in the category of theistic anarchists instead of an atheistic anarchist like Benjamin. Their different readings of Kafka may reflect this difference. 
"There was no sign of the Castle hill, fog and darkness surrounded it, not even the faintest gleam of light suggested the large Castle. K. stood a long time on wooden bridge that leads from the main road to the village, gazing upward into the seeming emptiness". ${ }^{28}$

But even in daylight, it is not exactly clear what $\mathrm{K}$. is looking at:

"On the whole the Castle, as it appeared from this distance corresponded to K.'s expectations. It was neither an old knight's fortress nor a magnificent new edifice, but a large complex made up of a few two-story buildings and many lower, tightly packed ones; had one not known that this was a castle, one could have taken it for a small town. K. saw only one tower, whether it belonged to a dwelling or a church was impossible to tell". 29

Later still, we get this observation where we see K. basically ordering his field of vision to produce the castle that must be there:

"The Castle, whose contours were already beginning to dissolve, lay still as ever, K. had never seen the slightest sign of life up there, perhaps it wasn't even possible to distinguish anything from this distance, and yet his eyes demanded it and refused to tolerate the stillness. When $\mathrm{K}$. looked at the Castle, it was at times as if he were watching someone who sat there calmly, gazing into space, not lost in thought and therefore cut off from everything, but free and untroubled; as if he were alone, unobserved; and yet it could not have escaped him that someone was observing him, but this didn't disturb his composure and indeed - one could not tell whether through cause or effect- the observer's gaze could not remain fixed there, and slid off. Today this impression was further reinforced by the early darkness, the longer he looked, the less he could make out, and the deeper everything sank into the twilight". ${ }^{30}$

This engagement with the castle, sets the tone for much of the novel; things that may or may not exist have an enormous, even central force in the life of K. and the villagers; in this village, theism (and hence, archism) run rampant. K. learns to organize his visual field around something that may not actually be there. Yet in a way, as with the previous discussion of God as well, the castle's actual presence is almost irrelevant; by learning to make this object the center of his vision, K. ensures that the castle is real, realer indeed than anything else in his life. To paraphrase Voltaire, if the castle didn't exist it would be necessary to invent it.

\footnotetext{
${ }^{28}$ Kafka 1998, 1.

${ }^{29}$ Ibid., 8.

${ }^{30}$ Ibid., 98-99.
} 
Not just the physical structure of the castle but its denizens take up an enormous amount of psychic space in this text. All of the villagers' life (and then, by extension, K.'s as well) is preoccupied with encountering and engaging with officials from the castle. One castle official, named Klamm (whose name is redolent of silence and secrets) is particularly sought after. K. begins a relationship with a young woman named Frieda once he discovers that she is Klamm's "mistress" (in fact it seems that she barely has anything to do with Klamm; her sightings of him are few and fleeting and it is not even clear if the person or persons that she is seeing is in fact Klamm himself). In this way relationality itself becomes entirely charged in relation to the castle and its imagined denizens. Life in the village is entirely structured by and run in conjunction with this mystical connection.

\section{A WHIFF OF DIVINITY}

One moment in the middle of the book gives a good sense of how K.'s entire life is oriented around this mystical central object. In this chapter, called appropriately enough "Waiting for Klamm," K. is told that Klamm's sleigh is in the courtyard of the Gentlemen's Inn, the inn which supposedly houses castle officials when they decide to stay overnight in the village. K. decides that, in order to be able to finally really talk to Klamm (up till now their communication has been only by letters and $\mathrm{K}$. is never quite sure if these letters really come from him), he will wait for Klamm by his sleigh. While he is waiting and freezing in the courtyard, he sees a coachman who invites him into the sleigh to have some cognac. Inside the sleigh, K. takes a sniff of this cognac. Kafka then writes that:

"[he] had to smile involuntarily; the smell was so sweet, so pleasing so much like praise and kind words from someone whom you're very fond of, thought you don't quite know what it is all about and do not want to know either and are simply happy in the knowledge that it is who is saying such things". 31

In a very claustrophobic novel where nothing is ever what it seems, where disappointment and failure mark every moment and people almost never seem to rise to any occasion, this is a singular moment. The smile on K.'s face may be the only sincere gesture he makes (and note that even then he smiles involuntarily).

Normally K. is always scheming, always anxious to know who to please and how to maximize his own position vis a vis the castle. Here, in this unscripted moment, $\mathrm{K}$. is getting a whiff of most pure expression of what the castle prom-

\footnotetext{
${ }^{31}$ Ibid., 103.
} 
ises. The cognac smells like praise and admiration from someone that he desperately wants to be praised and admired by. It is the smell of attention, attention from that ever elusive but most critical fundamental (and I might add divine) source at the center of his life.

Incredulous that this cognac could be real, the same substance as the ordinary cognac's that he had presumably been drinking all of his life, $\mathrm{K}$. asks the coachman "And this is supposed to be cognac?"32 The narrative goes on to say:

"But it was indeed cognac, oddly enough, warm and burning. How it changed as one drank, from something that was virtually no more than a bearer of sweet fragrance into a drink fit for a coachman. "Can it be?" $\mathrm{K}$. asked as though reproaching himself, and drank again". 33

Here we see the transformation from a magical, ethereal (but still actual) sensation back into the ordinary world of objects. Somehow the smell of the cognac, as opposed to the taste, transports $\mathrm{K}$. The taste is fine, but it is just what it is, regular cognac ("fit for a coachman"); the smell, on the other hand transcends the material object into a realm of pure joy. Here the joy and recognition always promised by the castle but never delivered is, for one single moment, actually manifest. Ironically, while waiting for Klamm (who never shows up of course although his secretary Momus does a moment later), K. experiences the briefest scent of what he believes that he is really looking for.

More accurately, as is often the case with Kafka's novels, the smell of the cognac offers a kind of transitional space between the material and the ideal. In this transitional space, there is an admixing or off-gassing of the kind of impossible perfection that is being projected onto the castle, merging itself, at least to some extent, with the humdrum realities of village life. Benjamin himself captures this quality when he writes of the village at the feet of the castle that:

"The air of this village blows about Kafka, and this is why he was not tempted to found a religion. The pigsty which houses the country doctor's horses; the stuffy back room in which Klamm, a cigar in his mouth, sits over a glass of beer; the manor gate which brings ruin to anyone who knocks on it - all these are part of this village. The air in the village is permeated with all the abortive and overripe elements that form such a putrid mixture. This is the air that Kafka had to breathe throughout his life. He was neither mantic nor the founder of a religion. How was he able to survive in this air?" 34

\footnotetext{
32 Ibid.

33 Ibid.

${ }^{34}$ W. Benjamin, 1996, 806.
} 
Benjamin here is attesting in a sense to Kafka's own atheism ("he was not tempted to found a religion.") Somehow for Kafka it was enough to imbibe the stenches of the village; he knew that these stenches somehow conveyed the reality that the villagers sought in the castle itself. If the visual field of the village was overwritten by the need to see a castle that may or may not have been there, the olfactory field was infused with the very thing sought, not in the sense of having true access to the castle as such but more in the sense of seeing that ordinary life itself possesses all that the castle promises. Those divine smells are not coming from the castle at all but from the village itself. Here, it is not the village that gets its life from the castle but the other way around; the castle gets its sense of reality, however problematic that may be-- from the fumes and off-gassing of the actual and living village.

The interface that these smells (both good and bad) offer is not therefore so much a reflection of an actual connection between the materiality of the village and the divine essence of the castle but more a sign that ordinary life itself can be rendered magical. The real trick of atheism, which utterly eludes K. himself throughout this novel (at the end of the unfinished novel, $\mathrm{K}$. is no closer to any kind of actual relationship with the castle then when it begins and Kafka purportedly told Brod that he planned at the end of The Castle to have K. simply die of exhaustion) is to enjoy these smells without needing to think that their sources were external — and by necessity — to ordinary life.

\section{THE VILLAGE ATHEISTS: AMALIA AND HER FAMILY}

Of course, as already noted, K. does nothing of the kind. Yet, if K. himself is hopelessly entangled with the phantasms that he is chasing, there is at least one family in The Castle who do effectively live an atheist life in a village which is otherwise completely subsumed by theistic devotion. This is the family of Barnabas, himself a messenger who serves as an early intermediary between $\mathrm{K}$. and the castle (at least so we are told). Barnabas has two sisters, Amalia and Olga who are singularly important characters in the book because, in a village composed of nothing but liars, these two (and Barnabas as well to some extent) seem to tell the truth (or the closest thing to truth that you are going to get in a Kafka novel).

For all of his own scheming and lying, $\mathrm{K}$. is drawn to the family initially by a kind of gaze that he attributes to all of them but especially to Amalia. Kafka describes her gaze as being

“cold, clear, as immobile as ever, it wasn't directly fixed on what she was observing, but instead — and this was unsettling — went past it, only slight, ever so imperceptibly, but undeniably so; it didn't seem to be 
weakness, embarrassment, or dishonesty that caused this but rather a constant desire for solitude that dominated all other feelings and that she herself had perhaps only become conscious of in this way". ${ }^{35}$

In a novel where everyone is ceaselessly engaged in organizing their visual field to see the castle, Amalia's gaze isn't fixated on an object (or in this case the object) but just past it. And, where everyone is scheming over what kinds of access other people have or don't have in terms of castle officials (the entire social hierarchy of the village is completely dominated by this pastime), Amalia seeks solitude. K. finds her gaze, and his impressions of this family more generally as being "not inherently disagreeable but rather proud and honest in its reserve."36

At one point K. says to her "You're always so sad, Amalia...Is there something tormenting you?" 37 Amalia won't answer the question but after she leaves, Olga tells him everything.

Olga's narrative begins by radically calling into question all of the "truths" that have anchored K.'s existence since he came to the village. She offers for example that Barnabas may not in fact work for the castle, asking

"is it even Castle work that Barnabas is doing...he certainly does go into the offices, bur are the offices actually the Castle? And even if the Castle does have offices, are they the offices Barnabas is permitted to enter?"38

Olga also radically calls the existence of Klamm himself into question, saying:

"Now [Barnabas] has been assigned to Klamm, to speak with him face to face. But is it really so? Well yes, it is indeed so, but then why does Barnabas doubt that the official identified as Klamm really is Klamm?"39

$\mathrm{K}$. is stupefied at this statement. He says: "But Olga...surely you don't mean to turn this into a joke; how can there be any doubt about Klamm's appearance, his appearance is well known, I've seen him myself." ${ }^{40}$ Olga assures him that she is not joking. She goes on to deconstruct much of what K. has believed up till this time. She tells him that:

\footnotetext{
${ }^{35}$ Kafka 1998, 167.

${ }^{36}$ Ibid, 167-168.

${ }^{37}$ Ibid., 168.

${ }^{38}$ Ibid., 174.

${ }^{39}$ Ibid., 175.

${ }^{40}$ Ibid.
} 
“what emerges from [the villager's]mixture of sightings, rumors and distorting ulterior motives is a picture of Klamm that is probably correct in its essential features. But only in its essential features. Otherwise it is variable and perhaps not even as variable as Klamm's real appearance. They say he looks completely different when he comes into the village and different when he leaves it, different before he has a beer, different afterwards, different awake, different asleep, different alone, different in conversation, and, quite understandably after all this, almost utterly different up there at the Castle". ${ }^{41}$

In saying these things, Olga is not entirely dismissing the possibility that Klamm is real but she is undermining the collective sensorium that has produced a single individual known as Klamm. She goes on show that the messages K. thinks he is receiving from Klamm may not be from him after all and that there is, in general, a lot of assumptions and filling in of blanks (to put it mildly) when it comes to the way that the villagers decipher the will and presence of any castle officials.

In hearing this, K. resists Olga's narrative in its entirety. He suggests that Barnabas, who is the source of much of this information, is simply too immature and inexperienced to be credible. But Olga continues her narrative. She finally gets to the core of her point, telling the story of Amalia's involvement with another castle official named Sortini (not to be confused with Sordini who is an entirely different person). There is a festival for the village's Firemen's Association - of which Olga and Amalia's father is a member--and Sortini comes to represent the castle for the occasion. When he shows up, Sortini, who seemed utterly indifferent to the festival itself, lays eyes on Amalia and is instantly and visibly taken with her. The next morning he sends a message to Amalia demanding that she go to the Gentlemen's Inn at once. Olga says that the letter was excessively vulgar and left little to the imagination about what Sortini had in mind. This kind of thing was in fact normal for the village. According to Olga, most of the young women in the village seem to long only for this kind of attention despite Sortini's clear, and all too tangible, repugnance (Olga says that had Sortini asked her even she would have gone to him). But Amalia was different. She refused to go see him. As a result, Olga said, a curse was put on the family. The father went from being happy and bright to near catatonic. The mother deteriorated as well and they were forced to give up their home and move to a much worse living space. Now Amalia spends all of her time feeding her parents who have become complete invalids. They become social pariahs and it was only by a miracle that Barnabas got a job (which supports the whole family).

${ }^{41}$ Ibid., 176. 
The whole family suffered, but Amalia had a special burden. Olga said finally of her situation that:

"She bore more than the rest of us; it's incomprehensible that she bore it and is still living among us today...Amalia not only bore the sorrow [which they all did] she also had the sense to see through it, we saw only the consequences, she saw the cause, we hoped for some little remedy or other, she knew everything had already been decided... she stood face to face with the truth and lived and endured this life then as now. How much better things were for us in all our misery than for her". ${ }^{4}$

Here we see a relatively clear (for Kafka) depiction of atheism. Amalia could be said to be the only atheist in town (with Olga somewhat on the margins; as for K. himself, he remains entirely on the side of mystical attachments; he interprets much of what Olga says as an attack on Frieda since she, after all readily agreed to be first Klamm's mistress and then K.'s). Amalia alone seems to have the strength to face the truth, the fact that there is no truth. She sees the castle for what it is; leaving aside the question of its existence (which is however paradoxically not the most critical question to ask about it since it has an effect whether it exists or not), Amalia alone sees the pettiness, the vindictiveness, the greed and selfishness of what passes for authority in the village. The villagers are like slaves to the castle; they seem to actively seek being oppressed by it. The women in the village pay an especially high price since they are particularly affected by the predations of the castle officials (who seem to be all men and straight men at that). Only Amalia can see that officials have nothing to offer the villagers but subordination and abuse. Existent or not, the very idea of the castle is enough to create endless hierarchy and taxonomization in the village; it is the very epitome of mythic violence.

In this impossible situation, only Amalia has the temerity to look all of that in the face (because this is the "truth" that she is facing) and say no. She offers a kind of one woman general strike against the archism that mythic violence has produced in this village. Her family, due to their loyalty to her (Olga says that for all that he suffered for her decision, her father never gave her a word of reproach for what she did) is dragged into her situation but they don't quite share her point of view (with Olga again as a possible exception). They merely bear their suffering. They feel their loss of social status and other material suffering but they still seem to regret the loss of what Amalia alone realizes is no loss at all. They remain bought into the phantasms and promises of archism. Amalia alone knows otherwise.

${ }^{42}$ Ibid., 210. 


\section{HOLLOWING OUT THE CASTLE}

In thinking of Kafka's own treatment of God and ultimate powers in The Castle, it is worth noting that he only mentions the ultimate castle lord by name one time: "Count Westwest." 43 The name itself is an absurdity; it seems clearly designed by Kafka to belittle rather than display the grandeur of the heights of the castle. If we think of The Castle along the lines of Nietzshe and Benjamin's subversion of the role of God, this may be one indication that Kafka is a kindred spirit when it comes to using God (or some stand in for God) as a way to defeat all that God is evoked for, all of the mythic violence that pays lip service to a God that it uses only to assert whatever local and terrestrial whim it wishes to realize at any given time.

Yet, taking the novel as a whole, The Castle could be considered to be a work that goes well beyond what either Nietzsche or Benjamin attempt by depicting the dismantling of God's effect on earth from an entirely terrestrial perspective. Both Nietzsche and Benjamin allow themselves to take on the perspective of the divine. Nietzsche adopts such perspectives through figures like his prophet Zarathustra, although, as I've already argued, those perspectives are usually meant as ways to lure archist subjects who are only interested in such things (just as K. is only interested in Klamm's cognac and mistresses) in order to disappoint them And Benjamin openly speaks of God's perspective, even as he does so to do battle with the way that God is otherwise depicted.

But K.'s sojourn in the village beneath the castle offers no such divine viewpoint; the novel is entirely bound by human limitations. To unmake any sense of divine vision and presence from this perspective is all the more remarkable because there is no way that Kafka — or the reader-- can know for sure what he is dealing with when he contends with what passes for divine authority.

What Kafka does quite readily show us is that the lies attributed to divinity, or to the castle in this case, are not particularly impressive, not all that beguiling. When K. first approaches the castle, Kafka writes:

Keeping his eyes fixed upon the Castle, K. went ahead, nothing else mattered to him. But as he came closer he was disappointed in the Castle, it was only a rather miserable little town pieced together from village houses, distinctive only because everything was perhaps built of stone, but the paint had since flaked off, and the stone seemed to be crumbling. Fleetingly, K. recalled his old hometown, it was scarcely inferior to this so-called Castle; if K. had merely wanted to visit it, all that wandering

${ }^{43}$ Ibid., 2. 
would have been in vain, and it would have made more sense for him to visit his old homeland again, where he had not been in such a long time. ${ }^{44}$

Here we see that $\mathrm{K}$. finds the castle disappointing. ${ }^{45}$ As previously noted, $\mathrm{K}$. had to learn to see the castle in the first place but now we also see that he has to learn to see it as it wishes (or is thought to wish) itself to be seen. It must not only be seen but seen as splendid and desirable, as the source of all possible happiness and passion in life. Kafka, partially through the character Amalia but also through K.'s own perspective (before he covers it over with devotion to myth) shows the way that this image is so easily dismissed; it's magnificence and power rests entirely on the desire of the villagers to keep it well above them, to keep themselves enslaved to its lures. This reveals that the kinds of mythic and archist powers that Kafka depicts in The Castle are unexpectedly vulnerable, requiring a fairly deep level of cooperation from their subjects in order to "exist" at all.

What then do we make of the fact that the only atheist in town is also the most miserable person in the village (recall how K. asks Amalia why she is always so sad)? Does this mean that to go against the grain, to refuse to see what isn't there and to refuse to worship the forms that mythic violence produces for us means to give up on happiness? To put this in terms of the novel, is it possible to have what the smell of Klamm's cognac suggested to K. without the necessity in believing in Klamm himself?

The possibly sad but critical answer to this question is no. Since the smell evokes something unreal (even though it has very real effects, very powerful influences on K. amongst others) there is no way to have that kind of delight without recourse to the mythic systems that promise that and more. But look at the price that K. has paid for that sniff of cognac! He has enslaved himself. He loves Frieda, who is not a terrible person by any means, but who is someone fully bound up with the love of what does not exist. Worse yet, it seems that Frieda is afflicted with the desire to submit herself to what doesn't exist; her interest in K. doesn't stem from his charms - in fact she doesn't seem to like him at all-- but rather from his own claims to have connections to Klamm. And the same goes for his feelings for her; their love for one another is entirely mediated by Klamm himself. Falling for the allure of heaven, K. has a life in which he doesn't really live at all.

\section{CONCLUSION: ANARCHISM AND ATHEISM}

Amalia may be sad but at least she is living in the face, not of what is true but rather what is not true. Part of her sadness however may be due to the fact that

\footnotetext{
${ }^{44}$ Ibid., 8.

${ }^{45}$ Disappointing Vision!
} 
she is all alone in her insight. She is in a community of one surrounded by true believers. Amalia may be the only atheist in the village but she is also, therefore the only openly practicing anarchist. The same "a" in both cases represents not just a negation as in "not theist" and "not archist" but also a positive, an alternative way of thinking and being. But it is difficult, if not impossible, to be an anarchist all by herself. Anarchism is a political stance, it is a collective position and Amalia can't simply hold the collective in herself' she actually needs a collective to exist as such, to interact with others, to produce together the kinds of decisions and judgments that the villagers believe can only be done by the denizens of the castle (and their representatives in the village). Without the reality of that collectivity, Amalia is indeed mostly just sad, her atheism does not get her all that far; she is like the analysand in therapy who sees all of her problems but doesn't really have the means to do anything about it. Atheism gives Amalia the correct diagnosis but anarchism is required to make a change. Otherwise Amalia just suffers in a world that she knows all too well (along with her family).

Somewhat more precisely, I think that everyone in the village is an anarchist, just as we all are, on some level anarchists, living out horizontal forms of life that the castle - or archist entities more generally — parasitically feeds off of. But if people don't acknowledge their own horizontal forms of authority, the value of their own life and interactions with others, then their anarchism is, in a sense, dormant, unaware of its itself even as it always remains available for an awakening.

Although in the novel The Castle, there is none of this kind of self-aware collectivity afoot, we, the readers of this text, need not be so constrained. We can see what Amalia sees plainly, what K. resists seeing with every fiber of his being. It is important not to make light of the disappointment and even despair that $\mathrm{K}$. initially feels when he sees the castle and which Amalia feels every day. Disappointment must follow the loss of so much that is promised, of a kind of grand meaning and narrative arc for the universe that each person is guaranteed to be very much a part of. In practice, of course, many people: black and brown people, poor people, women, queers, trans people, disabled people and others, realize that what they have been promised is not what they are going to get. But even the apex predators, the rich straight cis gendered white able bodied man, cannot have what is promised. They will eventually die; even they can't have everything promised by the heady scent of that cognac. We must all be as brave as Amalia to take that all important first step; to embrace atheism. The second step, the move towards an avowed and collective form of anarchism should in fact be much easier. For, as Benjamin shows us, the whole time that the village is obsessed with the castle and its denizens, they are living. Those stenches and airs are in one way a miasmic set of gases that gets us to believe in things like law and nature and God but they are also the air that we breath. Benjamin's question of "how was 
[Kafka] able to survive in this air?" may speak to the way that Kafka knew what he was inhaling better than the characters in his novel (with the exception once again of Amalia). But even those of us who get high off the vapors of archism are at the same time once again living an ordinary life, a life among others. The anarchism that comes as a result of atheism is actually an anarchism that we've all already long been practicing. We've simply given credit for that life and any delights that it may bring to us, to the empty or non-existent castle that lies amidst us.

Let us recall Benjamin's claim that "divine violence is pure power over all life for the sake of the living." Although human beings can't act as agents of divine violence, all of us live in the space that that violence has created, a space that frees us, at least potentially from the predations of mythic violence. We all are the living creatures that divine violence serves; it allows us the chance (but only that) to not only live an anarchist life but to know that we live one. This is the step that Amalia cannot take by herself but that we can all take together. Amalia's rebellion against theism shows that there are possibillities beyond disappointment, even if Amalia herself never gets there.

The great and central paradox to all of this is that it almost seems necessary to believe in God to stop believing in God. That is to say, atheism seems to require some kind of reckoning with divinity in order to overcome its malicious and fraudulent effects on us. Amalia had to look in the face not simply the absence of some divine order but also, and just as critically, the effect that divine order hadexistent or not - on the world. We must therefore take the occult theology that underlies our political, legal, economic and social lives seriously in order to combat it. Kafka's novel The Castle shows us that this can be done without a necessary recourse to an idea of God per se but we do need, as Amalia does, to face our tormentors. Rather than ask does Klamm exist or does Sortini exist? Amalia must ask first and prior to that question: what do these figures ask of me? Do I want to serve them in the way that they ask me to? Only after she has asked that question can she move on to the next question: do these figures exist? A possible proof that these steps can't be taken out of order lies in the fact that Olga readily admits that Klamm may not exist but she is not ready to say that he therefore holds no promise for her. She remains trapped in, rather than freed up by, a different - and partially suspended - form of disappointment.

In thinking about the value of atheism in a purportedly post-secular world (I say purportedly because once again I am not convinced that we've ever been truly secular) we see both its value and its limitations. It is necessary to confront the mythic basis of what oppresses the living. But it is equally critical not to think that atheism is enough. Amalia and her family show what an awful fate it could be to rest with only that conclusion. Just as one cannot move straight from 
archism to anarchism without engaging with atheism (otherwise all the phantasms that atheism counters will come roaring back) so too one cannot think that atheism is in and of itself a complete response to mythic violence. In the space afforded by atheism and anarchism alike (two terms that I think should always be associated with one another) we find the space for what might finally be called human freedom and that, surely, is worth giving up the occasional magical sniff of cognac. 


\section{BIBLIOGRAFIA}

Alter, Robert. 1991. Necessary Angels: Tradition and Modernity in Kafka, Benjamin and Scholem. Cambridge, MA: Harvard University Press.

Aristodemou, Maria. 2014. Law, Psychoanalysis, Society: Taking the Unconscious Seriously. London: Routledge.

Asad, Talal. 2003. Formations of the Secular: Christianity, Islam, Modernity. Stanford: Stanford University Press.

Asad, Talal / Brown, Wendy / Butler, Judith/ Mahmood, Saba. 2013. Is Critique Secular?: Blasphemy, Injury and Free Speech. New York: Fordham University Press.

Benjamin, Andrew. 2013. Working with Walter Benjamin. Edinburgh: Edinburgh University Press.

Benjamin, Walter. 1996. "Franz Kafka: on the Tenth Anniversary of his Death". In Walter Benjamin: Selected Writings Vol. 2, 1927-1934, editors Michael W. Jennings, Howard Eiland, and Gary Smith. Cambridge, MA: Harvard University Press.

Benjamin, Walter. 1996. "The Meaning of Time in the Moral Universe". In Walter Benjamin: Selected Writings, Vol 1. 1913-1926, editors Marcus Bullock, Michael W. Jennings. Cambridge, MA: Harvard University Press.

Chabbert, Marie. 2018. "On Becoming Secular: Gilles Deleuze and the Death of God". Working Papers in the Humanities 12: 50-59.

Cohn, Jesse. 2011. “'Don't Trust Anybody, Not Even Us': Kafka's Realism as Anarchist Modernism". Studies in 20 $0^{\text {th }}$ and $21^{\text {st }}$ Century Literature 35-2.

Connolly, William. 2002. Neuropolitics: Thinking, Culture, Speed. Minneapolis, MN: University of Minnesota Press.

Connolly, William. 2011. A World of Becoming. Durham, NC: Duke University Press.

Connolly, William. 1999. Why I Am Not a Secularist. Minneapolis, MN: University of Minnesota Press.

Connolly, William. 2011. "Some Theses on Secularism". Cultural Anthropology 26: 648-56.

Critchley, Simon. 2014. The Faith of the Faithless: Experiments in Political Theology. New York: Verso.

Deleuze, Gilles. 1983. Nietzsche and Philosophy. New York: Columbia University Press.

Derrida, Jacques. 1983. "Plato's Pharmacy”. In Derrida, Jacques. Dissemination. Chicago: University of Chicago Press.

Girard, René. 1988. "The Founding Murder in the Work of Friedrich Nietzsche". In Violence and Truth: On the Work of René Girard, edited and with introduction by Paul Dumouchel. Stanford: Stanford University Press.

Heidegger, Martin. 2002. "Nietzsche's Word: 'God is Dead'”. In Heidegger: Off the Beaten Track. New York: Cambridge University Press.

Kafka, Franz. 1998. The Castle. New York: Schocken Books. 
Kantorowicz, Ernst. 1957. The Kings Two Bodies: A Study in Mediaeval Political Theology. Princeton, NJ: Princeton University Press.

Mangabeira Unger, Roberto. 2016. The Religion of the Future. New York: Verso Press.

Mahmood, Saba. 2015. Religious Difference in a Secular Age: A Minority Report. Princeton, NJ: Princeton University Press.

Moses, Stéphane. 1999. “Gershom Scholem's Reading of Kafka: Literary Criticism and Kabbalah". New German Critique 77 (Special Issue on GermanJewish Religious Thought):149-167.

Newman, Saul. Political Theology: A Critical Introduction. Cambridge, UK: Polity Press.

Nietzsche, Friedrich. 1956. The Genealogy of Moral. New York: Doubleday.

Nietzsche, Friedrich. 1969. Thus Spoke Zarathustra. New York: Penguin.

Nietzsche, Friedrich. 1974. The Gay Science. New York: Vintage Book.

Nietzsche, Friedrich. 1993. Ecce Homo: How One Becomes What One Is. New York: Penguin.

Sanín-Restrepo, Ricardo. 2016. Decolonizing Democracy: Power in a Solid State. New York: Rowman \& Littlefied.

Scholem, Gershom (editor). 1992. The Correspondence of Walter Benjamin and Gershom Scholem. Cambridge, MA: Harvard University Press.

Watkin, Christopher. 2011. Difficult Atheism: Post-Theological Thinking in Alain Badiou, Jean-Luc Nancy and Quentin Meillassoux. Edinburgh: Edinburgh University Press.

Weber, Max. 1985. The Protestant Ethic and the Spirit of Capitalism. London: Allen and Unwin. 